\title{
Kebijakan Hukum Pidana Perampasan Aset Tindak Pidana Narkotika di Indonesia
}

\section{The Criminal Policies of Asset Expropriation on Narcotic Crime in Indonesia}

\author{
Arifuddin \\ Kepolisian Negara Republik Indonesia \\ E-mail: Bripkaarifuddin@gmail.com \\ Handrawan \\ Pascasarjana Universitas Halu Oleo \\ E-mail: handrawansaranani84@gmail.com \\ Oheo K. Haris \\ Pascasarjana Universitas Halu Oleo \\ E-mail:oheokh@gmail.com
}

\begin{abstract}
This paper is aimed at analyzing narcotic revenue assets which is suspect credit guarantee to run foreclosure. Secondly, it is investigating of separated narcotic revenue assets of suspect credit guarantee of foreclosure by means of criminal policies. This study applied legislations, cases, and concept approaches. This research answered that narcotic revenue assets which is suspect credit guarantee of foreclosure was under investigator discretionary power to reveal narcotic crime, as well as that narcotic is extra ordinary crime. Besides, on behalf investigator discretionary power that has to foreclosure the suspect narcotic asset by means of legal policy as legal base to fulfill the empty norm.
\end{abstract}

Keyword: Policies; Expropriation; Narcotics

Abstrak: Penelitian ini ditujukan pada analisis aset hasil penjualan Narkotika yang masih dalam jaminan kredit tersangka dapat dilakukan penyitaan. yang kedua adalah untuk menganalisis pemisahan aset hasil penjualan Narkotika yang masih dalam jaminan kredit tersangka dalam pendekatan kebijakan hukum pidana Riset ini menggunakan pendekatan undang-undang, kasus, dan konsep. Hasil penelitian ini menjawab bahwa aset hasil penjualan narkotika yang masih dalam tanggungan kredit tersangka dapat dilakukan penyitaan oleh penyidik sebagai bentuk kepentingan penegakkan hukum di bidang pembuktian atas tindak pidana narkotika yang merupakan tindak pidana extraordinary crime. Selain itu alasan diskresi yang melekat pada penyidik sebagai hak yang diberikan oleh hukum menjadi dasar penilai penyidik untuk melakukan penyitaan. Pemisahan aset hasil penjualan narkotika yang masih dalam tanggungan kredittersangka dalam pendekatan kebijakan hukum pidana sebagai dasar kekosongan norma aturan.

Kata kunci: Kebijakan; Perampasan; Narkotika 


\section{PENDAHULUAN}

Dalam praktiknya penyitaan terhadap aset yang diperoleh melalui tindak pidana Narkotika masih menyisakan problem, di mana aset yang dirampas telah bersatu dengan aset orang lain yang berasal dalam kausa yang halal. Salah satu contoh adalah upaya penyitaan yang dilakukan penyidik terhadap perumahan di mana perumahan tersebut dibeli secara kredit oleh pelaku yang belum lunas. Obyek perumahan tersebut secara hukum menyisakan permasalahan yang perlu di selesaikan secara hukum sebab terdapat hak orang lain di dalam perumahan tersebut. Tindakan penyitaan yang dilakukan terhadap obyek perumahan tersebut merupakan suatu yang wajib dilakukan oleh penyidik sebagai bentuk perintah Undang-undang dan penjamin proses penegakan hukum. Namun di sisi lain obyek penyitaan tersebut jika dilakukan akan melanggar hak-hak privat hukum orang lain. Dengan demikian, perbuatan yang dituduhkan itu merupakan perbuatan yang diancam pidana dan ditetapkan kesalahan, terdakwa, maka diputuskan tentang pidananya. ${ }^{1}$

Permasalahan tersebut jika dikaji dari perspektif hukum terdapat benturan kepentingan hukum terlebih di dalam norma pelaksanaan penyitaan tidak menjelaskan secara eksplisit tentang keadaan hukum tersebut. Oleh sebab itu perlu dilakukan penalaran hukum dan atau pembaharuan hukum baru untuk menyelesaikan keadaan hukum demi menjamin kepastian hukum bagi penyidik dalam melakukan tindakan penegakan hukum sebagaimana yang di berikan wewenang oleh Undang-undang. Selain itu juga memberikan jaminan kepastian dan keadilan hukum bagi subyek hukum yang lain agar tindakan penyitaan yang dilakukan secara hukum tidak melanggar kepentingan hukum privat orang lain. Oleh sebab itu hukum harus hadir demi menjaga kepentingan hukum keduanya.

Ketiadaan norma baik pada level Undang-undang maupun Surat Edaran Mahkamah Agung maupun dalam peraturan Kapolri terkait dengan mekanisme penyitaan benda yang telah menyatu dengan benda milik orang lain mengakibatkan terjadinya kesulitan bagi penyidik dalam mengeksekusi benda sitaan tersebut. Hal lain yang dihadapi penyidik adalah mekanisme pemisahan benda sitaan tersebut apakah pemisahan dilakukan sebelum penyitaan dilaksanakan ataukah menunggu putusan pengadilan kemudian pemisahan obyek sitaan dilaksanakan. Kepentingan hukum terhadap benda sitaan sangat kompleks. Di satu sisi penyitaan wajib dilaksanakan untuk kepentingan hukum publik namun di sisi lain jika

1 Yusuf Mars, Herman, Handrawan, "Analisis Hukum Pembuktian Terhadap Putusan Bebas dalam Kasus Tindak Pidana Narkotika (Studi Putusan Pengadilan Negeri Kendari Nomor: 405/Pid.Sus/2016/PN. Kdi," Halu Oleo Legal Research, Volume 1, Issue 2, August 2019, hlm. 194-208. 
penyitaan tetap dilaksanakan maka kepentingan hukum privat subyek hukum yang lain akan terganggu.

\section{METODE PENELITIAN}

Penelitian ini menggunakan tipe penelitian hukum yaitu suatu proses untuk menemukan aturan hukum, prinsip-prinsip hukum, maupun doktrin-doktrin guna menjawab isu hukum yang dihadapi terkait dengan penyitaan aset hasil penjualan narkotika yang masih dalam tanggungan kredit tersangka. Pendekatan masalah yang digunakan dalam penulisan ini adalah pendekatan perundang-undangan (statute aprroach), pendekatan kasus (case approach) dan pendekatan konseptual (conceptual aprroach), dengan maksud untuk menganalisis konsep hukum mengenai penyitaan aset hasil penjualan narkotika yang masih dalam tanggungan kredit tersangka. ${ }^{2}$

\section{ANALISIS DAN PEMBAHASAN}

\section{Aset Hasil Penjualan Narkotika yang Masih dalam Tanggungan Kredit Tersangka Dapat Dilakukan Penyitaan}

Tindakan penyitaan hanya dapat dilakukan oleh penyidik dengan izin Ketua Pengadilan Negeri setempat. Dalam keadaan yang sangat perlu dan mendesak, bilamana penyidik harus segera bertindak dan tidak mungkin untuk mendapatkan surat izin terlebih dahulu, tanpa mengurangi ketentuan keharusan adanya izin Ketua Pengadilan, penyidik dapat melakukan penyitaan hanya atas benda bergerak dan untuk itu wajib segera melaporkan kepada Ketua Pengadilan Negeri setempat guna memperoleh persetujuan ${ }^{3}$.

Konsepsi penyitaan dalam sistem hukum Indonesia yang meliputi, tujuan, mekanisme penyitaan dan dalam keadaan seperti apa penyitaan dapat dilakukan serta perbedaannya dengan penggeledahan serta perampasan dengan segala kepentingan hukum yang berbeda antara satu dengan yang lain. Namun demikian di dalam ketentuan Pasal 38-46 KUHAP tidak mengatur satu pasal pun tentang pelaksanaan sistem penyitaan terhadap benda/barang yang sedang dalam tanggungan kredit. Dalam ketentuan Pasal 38-Pasal 46 KUHAP hanya mengatur penyitaan yang dalam keadaan normal dimana wujud benda/barang sitaan masih utuh dan tidak sulit untuk dipisahkan. Berbeda kemudian terhadap barang/benda sitaan yang sudah

2 Peter Mahmud Marzuki, Penelitian Hukum, Jakarta: Kencana Prenada Media Group, Surabaya, 2013, hlm. 93.

3 Bima Priya Santosa, dkk., Lembaga Pengelola Aset Tindak Pidana, Jakarta: Paramadina Public Policy Institute, 2010, hlm. 12. 
menyatu dalam bentuk rumah dimana rumah tersebut masih dalam tanggungan kredit dan telah bercampur dengan harta yang sah dengan orang lain.

Ketiadaan norma aturan tersebut mengakibatkan penyidik kesulitan untuk melakukan tindakan penyitaan karena baik KUHAP maupun peraturan Kapolri tidak menjelaskan secara komprehensif tentang keadaan penyitaan yang telah bercampur dengan harta orang lain. Keadaan hukum tersebut tentunya telah menghambat proses penegakkan hukum di Indonesia apalagi penyitaan memiliki kedudukan yang sangat penting dalam pembuktian di dalam pengadilan bukan hanya sekedar kepentingan penyidikan. Untuk itu perkuatan dalam sistem hukum Indonesia khususnya dibidang penyelenggaraan hukum acara pidana khususnya di bidang penyitaan terhadap keadaan hukum dimana objek sitaan masih dalam tanggungan kredit.

Dalam pandangan penulis terkait keadaan tersebut maka aset hasil penjualan narkotika yang masih dalam tanggungan kredit tersangka tetap dapat dilakukan penyitaan oleh penyidik sebagai bentuk kepentingan penegakkan hukum di bidang pembuktian atas tindak pidana narkotika. Tidak diaturnya tentang kebolehan atau tidaknya penyitaan terhadap aset yang masih dalam tanggungan kredit dan atau masih menyatu dengan milik orang lain secara sah di dalam KUHAP ataupun pada tingkat teknis Perkap Kapolri bukan berarti penyitaan tersebut tidak dapat dilakukan karena ada kepentingan dan atau kegentingan hukum yang mendesak bagi penyidik dalam rangka penegakkan hukum di bidang narkotika yang merupakan tindak pidana extraordinary crime. Selain itu alasan diskresi yang melekat pada penyidik sebagai hak di berikan oleh hukum menjadi dasar penilaian penyidik untuk melakukan penyitaan terhadap aset yang masih dalam tanggungan kredit sebab apabila hal tersebut tidak dilakukan maka penegakkan hukum dan pencegahannya akan sulit tercapai. Menurut paham legalisme dan positivisme yuridis menekankan pandangan bahwa hakikat hukum adalah hanya sebatas hukum yang tertulis (undang-undang). ${ }^{4}$ Keadilan bukan merupakan tujuan utama dari penerapan hukum. Adil atau tidak adil tidak menjadi persoalan, yang penting kepastian hukum tetap terjaga karena menurut aliran ini hukum semata-mata adalah untuk menjamin kepastian hukum, maka hakim tidak lain dari hanya sekedar corong undang-undang (bouche de la loi).

Jika dikaitkan dalam konteks penyitaan penyidik adalah corong undang-undang karena segala tindakkannya harus berdasarkan peraturan undang-undang secara kaku. Penyidik dalam melakukan penyitaan tidak diperkenankan melakukan penafsiran sebab secara hukum

4 Antonius Sudirman, Hati Nurani dan Putusannya Suatu Pendekatan dari Perspektif Ilmu Hukum Perilaku (Behavior Jurusprudence) Kasus Hakim Bismar Siregar, Bandung: Citra Aditya Bakti, 2007, hlm. 27. 
tugas menafsir hanya di letakkan kepada hakim dan ahli untuk melihat dan memutus suatu perkara yang diajukan kepadanya. Namun bagi penyidik keadaan tersebut menjadi tantangan dan keadaan yang tidak menguntungkan akibatnya banyak tindakan yang dilakukan penyidik dianggap salah oleh penuntut umum terkhusus dalam tindakan penyitaan aset terhadap harta yang telah menyatu dengan milik orang lain.

Penyidik dalam melakukan penyitaan terhadap objek sitaan yang masih dalam tanggungan kredit berupa rumah mendapatkan tantangan dan keberatan dari penuntut umum. Penuntut umum berpandangan bahwa rumah yang menjadi objek sitaan penyidik tidak perlu dilakukan penyitaan cukup penyitaan terhadap uang. Namun menurut penyidik berpandangan bahwa sangat tidak mungkin melakukan penyitaan terhadap uang karena uang tersebut sudah berubah bentuk menjadi rumah.

Argumentasi hukum penuntut umum berpandang penyitaan cukup ditujukan terhadap uang karena penuntut umum tidak akan mengalami kesulitan dalam pembuktian di pengadilan serta jika dalam bentuk uang akan mudah dilakukan eksekusi dan pengembalian terhadap negara sebagaimana yang dimaksud di dalam ketentuan Pasal 39 KUHP jo. Pasal 46 KUHAP barang-barang bukti tersebut dirampas untuk Negara." Adapun di dalam Pasal 39 KUHP disebutkan: (1) Barang-barang kepunyaan terpidana yang diperoleh dari kejahatan atau yang sengaja dipergunakan untuk melakukan kejahatan, dapat dirampas. (2) Dalam hal pemidanaan karena kejahatan yang tidak dilakukan dengan sengaja atau karena pelanggaran, dapat juga dijatuhkan putusan perampasan berdasarkan hal-hal yang ditentukan dalam undang-undang. (3) Perampasan dapat dilakukan terhadap orang yang bersalah yang diserahkan kepada pemerintah, tetapi hanya atas barang-barang yang telah disita.

Menurut penulis ada 2 alasan sosiologis yang penting bagi penuntut umum jika penyitaan ditujukan terhadap uang yakni: pertama, penuntut umum tidak ingin mengalami kesusahan dalam pembuktian karena dengan barang bukti uang akan mempermudah pelaksanaan pembuktian. Kedua, ada kesan mempersulit penyidik dalam tindakan penegakkan hukum di bidang penyitaan. Selain itu menurut penulis, ketentuan Pasal 39 KUHP jo. Pasal 46 KUHAP barang-barang bukti tersebut dirampas untuk Negara hanya ditujukan terhadap benda sitaan yang dalam keadaan belum menyatu dengan milik dan atau kepunyaan orang lain secara sah. Di Indonesia sendiri terutama di lingkungan para hakim, diakui ataupun tidak pemikiran yang berkembang lebih cenderung ke arah paham legalisme walaupun tidak dalam bentuk yang terlalu ekstrem. Kepastian hukum menjadi tujuan yang lebih utama daripada keadilan, paham ini berkembang di kalangan mereka yang menganggap bahwa keadilan merupakan sesuatu 
yang abstrak dan sangat subjektif, sehingga menurut pemikiran mereka bahwa yang adil itu adalah yang sesuai dengan aturan perundang-undangan.

Di kalangan hakim pada umumnya selalu ada kekhawatiran untuk menyimpang prinsip kepastian hukum daripada mengesampingkan keadilan substantif, karena secara logika akan lebih mudah berargumen dibalik logika kepastian hukum yang tertulis secara letterlijk dalam aturan undang-undang ketimbang harus mempertahankan keyakinan dengan dasar nilai keadilan yang abstrak. Kita bisa lihat ketika seorang Hakim Bismar Siregar melakukan terobosan dengan memperluas pengertian unsur "barang" dalam Pasal 378 KUHP5, walaupun secara sosiologis diakui merupakan penemuan hukum yang memberikan keadilan, namun secara legal formal terobosan seperti itu masih dianggap sebagai kekeliruan yang merusak nilai kepastian hukum. Penegakan hukum dengan menggunakan pendekatan manfaat tidak lain bertujuan untuk mengisi celah-celah kosong antara keadilan dan kepastian hukum, aliran pendukungnya disebut aliran utilitas yang menganggap bahwa tujuan hukum adalah sematamata untuk memberikan kemanfaatan atau kebahagiaan yang sebesar-besarnya bagi sebanyakbanyaknya warga masyarakat ${ }^{6}$. Idealnya keadilan, kepastian dan kemanfaatan hukum dapat dipersatukan dalam sebuah putusan sesuai kasus in concerto dengan menggunakan triangular concept, namun ketika antara keadilan dan kepastian hukum tidak dapat disandingkan secara bersamaan, maka hakim harus memilih di antara keduanya yang lebih mendatangkan kemanfaatan hukum bagi para pencari keadilan atau bagi hukum itu sendiri. ${ }^{7}$

\section{Mekanisme Memisahkan Aset Hasil Penjualan Narkotika yang Masih dalam Tanggungan Kredit Tersangka dalam Pendekatan Kebijakan Hukum Pidana}

Pengertian perampasan aset tindak pidana yang dimaksud dalam undang-undang ini adalah aset yang terkait dengan tindak pidana tetapi perampasannya tidak diputus berdasarkan putusan peradilan pidana (in personam). Pengertian perampasan aset seperti ini dikenal dengan istilah asset forfeiture (in rem), sementara istilah in rem belum ada padanannya dalam bahasa Indonesia. Oleh karena itu dipertimbangkan untuk menambahkan definisi aset tindak pidana dengan frasa kata in rem, sehingga menjadi "perampasan aset tindak pidana in

Antonius Sudirman, Op. cit., hlm. 212.

Achmad Ali, Menguak Teori Hukum (Legal Theory) dan Teori Peradilan (Judicialprudence) Termasuk Interpretasi Undang-Undang (Legisprudence), Jakarta: Kencana, 2009, hlm, 272.

7 Darmoko Yuti Witanto dan Arya Putra Negara, Diskresi Hakim: Sebuah Instrumen Menegakkan Keadilan Substantif dalam Perkara-Perkara Pidana, Bandung: Alfabeta, 2013, hlm. 18. Dalam Ade Mahmud, Pengembalian Aset Tindak Pidana Korupsi: Pendekatan Hukum Progresif, Jakarta: Sinar Grafika, 2020, hlm. 49. 
rem". ${ }^{8}$

Mengingat bahwa penuntutan dalam perkara ini objek harta benda yang terkait dengan tindak pidana tetapi tidak diputus dalam peradilan pidana (in personam), maka perlu untuk diberikan pengertian penuntutan dan penuntut umum yang berbeda dengan pengertian dalam KUHAP. Yang dimaksud dengan permohonan perampasan aset (in rem) adalah tindakan penuntut umum untuk mengajukan permohonan perampasan aset kepada pengadilan negeri setempat yang berwenang mengadili perkara pidana dalam hal dan menurut cara yang akan diatur kemudian dalam undang-undang dengan permintaan supaya diperiksa dan diputus oleh hakim di sidang pengadilan. ${ }^{9}$

Menurut penulis dari berbagai teori yang ada dalam konstruksi hukum pidana terdapat beberapa keadaan aset tindak pidana yang dapat dirampas yang diperoleh atau diduga dari tindak pidana aset, yaitu:

a. Aset yang diperoleh secara langsung atau tidak langsung dari tindak pidana termasuk yang telah dihibahkan atau dikonversikan menjadi harta kekayaan pribadi, orang lain atau korporasi baik berupa modal, pendapatan maupun keuntungan ekonomi lainnya yang diperoleh dari kekayaan tersebut;

b. Aset yang diduga kuat digunakan atau telah digunakan untuk melakukan tindak pidana;

c. Aset lainnya yang sah sebagai pengganti aset tindak pidana; atau

d. Aset yang merupakan barang temuan yang diduga berasal dari tindak pidana.

Uraian di atas menurut penulis secara teoritis menunjukkan bahwa tidak terdapat konstruksi hukum yang kuat terkait penyitaan aset tindak pidana yang hartanya telah bercampur dengan aset yang sah milik orang lain yang diperoleh bukan melalui perbuatan melawan hukum. Keadaan tersebut tentunya menjadi bagian dari kekosongan hukum yang ada saat ini di dalam hukum acara pidana. Kekosongan hukum tersebut perlu dikonstruksikan di dalam norma hukum baru yang memuat perintah tentang dibolehkannya perampasan aset terhadap barang/benda yang sudah bercampur dengan barang milik orang lain melalui undang-undangan yang baru. Norma perintah tersebut ditunjukkan kepada penyidik sebagai

8 Ramelan, Laporan Akhir Naskah Akademik Rancangan Undang-Undang tentang Perampasan Aset Tindak Pidana, Jakarta: Pusat Perencanaan Pembangunan Hukum Nasional Badan Pembinaan Hukum Nasional Kementerian Hukum dan Hak Asasi Manusia RI, 2012, hlm. 168.

9 NN, Laporan Hasil Penyelarasan Naskah Akademik Rancangan Undang-Undang tentang Perampasan Aset Tindak Pidana", Jakarta: Badan Pembinaan Hukum Nasional Kementerian Hukum dan Hak Asasi Manusia Republik Indonesia, 2015, hlm. 245-246. 
alat negara yang bertugas melakukan penegakan hukum untuk dapat mengeksekusi keadaan hukum tersebut sebagaimana yang diatur di dalam Undang-Undang Nomor 2 Tahun 2002 tentang Kepolisian Negara Republik Indonesia dan Undang-Undang Nomor 8 Tahun 1981 tentang KUHAP. Dalam mewujudkan konstruksi penyitaan yang ideal dan berkepastian hukum bagi penyidik maupun pihak-pihak yang memiliki hubungan hukum dengan objek sitaan, maka hanya dengan melalui proses kebijakan hukum pidana dapat terlaksana kepastian hukum melalui pengaturan baru dalam konstruksi RKUHAP dimasa yang akan datang. Sekalipun pernyataan di atas, namun hukum pidana selalu berlandaskan pada asas legalitas. Asas legalitas tercantum dalam Pasal 1 ayat (1) KUHP. Secara terminologi, makna ini berbunyi: "Tiada suatu perbuatan (feit) yang dapat dipidana, selain berdasarkan kekuatan ketentuan perundangundangan pidana yang mendahuluinya"10

Dalam Pasal 39 dan Pasal 1 butir 16 KUHAP telah dijelaskan prinsip hukum di dalam penyitaan suatu benda, tentang bagaimana benda tersebut dapat diberikan atau dilekatkan penyitaan. Selanjutnya, M. Yahya Harahap memberikan penjelasan mengenai prinsip hukum tersebut, bahwa benda yang dapat disita menurut Kitab Undang-Undang Hukum Acara Pidana ialah hanya benda-benda yang ada hubungannya dengan tindak pidana. Jika suatu benda tidak ada kaitannya atau keterlibatan dengan tindak pidana, terhadap benda-benda tersebut tidak dapat dilekatkan sita. ${ }^{11}$

Merujuk pada pendapat M. Yahya Harahap menurut penulis setuju dengan pandangan tersebut bahwa yang dapat dilakukan perampasan adalah hanyalah barang dan atau benda yang diperoleh dari hasil tindak pidana dan terhadap barang yang sah diperoleh tidak dapat dilakukan penyitaan. Namun demikian menurut penulis pendapat tersebut belum memberikan jawaban secara doktrinal bahwa bagaimana terhadap barang yang sudah menyatu apakah dapat dimungkinkan dilakukan perampasan atau tidak karena jika dirampas maka rumah pengembang akan mengalami kerugian karena dia tidak mendapatkan keuntungan lagi dari penjualan kredit tersebut dan secara tidak langsung pembayaran akan terhenti. Namun jika tidak dilakukan penyitaan maka akan memberikan dampak bagi penyidik dan penuntut umum dalam proses pembuktian nantinya yang dapat dimungkinkan pelaku tindak pidana narkotika tidak dapat dituntut dengan pasal pencucian uang dan atau pasal pemberatan lainnya. Kualifikasi benda atau barang dalam pengertian hukum meliputi yang berwujud, tidak

10 Arto Siswahyudi, Sabrina Hidayat, Oheo K.Haris, "Kebijakan Hukum Pidana dalam Pemidanaan Tindak Pidana Illegal Logging", Halu Oleo Legal Research, Volume 2, Issue 3, Desember 2020. hlm. 16.

11 M. Yahya Harahap, Pembahasan Permasalahan dan Penerapan KUHAP: Pemeriksaan Sidang Pengadilan, Banding, Kasasi dan Peninjauan Kembali, Jakarta: Sinar Grafika, 2007, hlm. 274-275. 
berwujud, bergerak, dan tidak bergerak. Pengertian benda atau barang seperti itu oleh hukum, tidak bisa dilepaskan dari pemilikan hak terhadapnya. Artinya, sejauh bisa ada hak yang melekat padanya, maka itu adalah benda atau barang dalam arti hukum. Oleh sebab itu, walaupun benda tak nyata wujudnya, tetapi karena benda itu bisa dimiliki maka hak yang ada di atasnya pun akan bisa dan boleh diperalihkan ${ }^{12}$.

Berdasarkan uraian pembahasan di atas dapat disimpulkan bahwa terdapat kekosongan norma aturan di dalam melakukan penyitaan terhadap objek sitaan yang telah menyatu dengan hak orang lain secara. Selain itu Rumbasan hanya berfungsi sebagai penyimpan bukan bertugas memisahkan keuangan karena fungsi keuangan tidak melekat kepadanya. Di dalam tindak pidana korupsi terdapat lembaga khusus yang di beri kewenangan oleh undang-undang untuk melakukan perhitungan kerugian negara dan bertugas memisahkan aset sitaan yang telah menyetu dengan milik orang lain secara sah menurut undang-undang. Kekosongan norma tersebut, maka penulis berpandangan bahwa perlu adanya lembaga tersendiri yang bertugas melakukan pemisahan aset sitaan yang telah menyatu atau yang masih dalam tanggungan kredit agar hak-hak privat subjek hukum yang lain tidak dilanggar. Selain itu pentingnya di bentuk lembaga tersendiri seperti dalam tindak pidana korupsi untuk mencegah terjadinya konflik kepentingan hukum antara lembaga penegak hukum dalam hal ini penyidik kepolisian negara Republik Indonesia dengan penuntut umum, Sebab kedua lembaga penegak hukum tersebut merupakan alat negara di bidang penegakan hukum yang saling bekerja sama dalam proses pembuktian.

Dalam konstruksi kebijakan hukum pidana di bidang penyitaan terhadap aset sitaan yang telah menyatu dan atau masih dalam tanggungan kredit tersangka maka sekiranya penulis mengajukan dua konsep kebijakan hukum pidana dimasa yang akan datang yakni:

1. Dibentuknya oleh negara dalam bentuk badan tersendiri sebagai langkah preventif dalam penjamin pelaksanaan tugas penyitaan khususnya tindak pidana narkotika dengan nama Lembaga Penjamin dan Penghitung Aset Hasil Tindak Pidana Narkotika (L2ASTN) yang berada di bawah Badan Pemeriksa Keuangan (BPK) atau BPKP Jika ditingkat provinsi;

2. Lembaga Penjamin dan Penghitung Aset Hasil Tindak Pidana Narkotika nantinya dapat menghitung dan memisahkan aset yang masih dalam tanggungan kredit sebelum putusan pengadilan;

12 Nikolas Simandjuntak, Acara Pidana Indonesia Dalam Sirkus Hukum, Jakarta: Ghalia Indonesia, 2009, hlm. 100. 
3. Pengaturan hukum Pemisahan Aset sitaan terhadap objek sitaan yang masih dalam tanggungan kredit dilakukan sebelum Putusan pengadilan dimaksudkan agar pengumpulan barang bukti dalam proses pembuktian bagi penyidik lebih berkepastian hukum serta menjamin perlindungan hukum bagi orang lain yang asetnya telah menyatu dengan hasil kejahatan narkotika;

4. Pengaturan hukum tentang tenggang waktu pemisahan dan penghitungan aset oleh Lembaga Penjamin dan Penghitung Aset Hasil Tindak Pidana Narkotika di dalam KUHAP;

5. Pengaturan hukum tentang mekanisme pengajuan pemisahan dan penghitungan aset oleh Lembaga Penjamin dan Penghitung Aset Hasil Tindak Pidana Narkotika oleh penyidik.

Uraian tersebut di atas merupakan bentuk kebijakan hukum pidana yang di formulasikan penulis dimasa yang akan datang yang perlu di atur di dalam KUHAP yang baru sebagai bentuk penjaminan kepastian hukum bagi penyidik dan orang lain dalam kerangka penegakan hukum di bidang penyitaan untuk kepentingan pembuktian di dalam hukum acara pidana.

\section{KESIMPULAN}

Berdasarkan hasil penelitian dan pembahasan yang telah diuraikan di atas, maka dapat ditarik kesimpulan bahwa aset hasil penjualan narkotika yang masih dalam tanggungan kredit tersangka dapat dilakukan penyitaan oleh penyidik sebagai bentuk kepentingan penegakkan hukum di bidang pembuktian atas tindak pidana narkotika. Tidak diaturnya tentang kebolehan atau tidaknya penyitaan terhadap aset yang masih dalam tanggungan kredit dan atau masih menyatu dengan milik orang lain secara sah di dalam KUHAP ataupun pada tingkat teknis Perkap Kapolri bukan berarti penyitaan tersebut tidak dapat dilakukan karena ada kepentingan dan atau kegentingan hukum yang mendesak bagi penyidik dalam rangka penegakkan hukum di bidang narkotika yang merupakan tindak pidana extraordinary crime. Selain itu alasan diskresi yang melekat pada penyidik sebagai hak di berikan oleh hukum menjadi dasar penilai penyidik untuk melakukan penyitaan. Selain itu, mekanisme memisahkan aset hasil penjualan narkotika yang masih dalam tanggungan kredit tersangka dalam pendekatan kebijakan hukum pidana sebagai dasar kekosongan norma aturan (1) Dibentuknya oleh negara dalam bentuk badan tersendiri sebagai langkah preventif dalam penjamin pelaksanaan tugas penyitaan khususnya tindak pidana narkotika dengan nama Lembaga Penjamin dan Penghitung Aset Hasil 
Tindak Pidana Narkotika (L2ASTN) yang berada di bawah Badan Pemeriksa Keuangan (BPK) atau BPKP Jika ditingkat provinsi; (2) Lembaga Penjamin dan Penghitung Aset Hasil Tindak Pidana Narkotika nantinya dapat menghitung dan memisahkan aset yang masih dalam tanggungan kredit sebelum putusan pengadilan; (3) Pengaturan hukum Pemisahan Aset sitaan terhadap objek sitaan yang masih dalam tanggungan kredit dilakukan sebelum Putusan pengadilan dimaksudkan agar pengumpulan barang bukti dalam proses pembuktian bagi penyidik lebih berkepastian hukum serta menjamin perlindungan hukum bagi orang lain yang asetnya telah menyatu dengan hasil kejahatan narkotika; (4) Pengaturan hukum tentang tenggang waktu pemisahan dan penghitungan aset oleh Lembaga Penjamin dan Penghitung Aset Hasil Tindak Pidana Narkotika di dalam KUHAP; dan (5) Pengaturan hukum tentang mekanisme pengajuan pemisahan dan penghitungan aset oleh Lembaga Penjamin dan Penghitung Aset Hasil Tindak Pidana Narkotika oleh penyidik.

\section{Daftar Pustaka}

\section{Buku}

Ali, Achmad, Menguak Teori Hukum (Legal Theory) dan Teori Peradilan (Judicialprudence) Termasuk Interpretasi Undang-Undang (Legisprudence), Jakarta: Kencana, 2009.

Harahap, M. Yahya, Pembahasan Permasalahan dan Penerapan KUHAP: Pemeriksaan Sidang Pengadilan, Banding, Kasasi dan Peninjauan Kembali, Jakarta: Sinar Grafika, 2007.

Mahmud, Ade, Pengembalian Aset Tindak Pidana Korupsi: Pendekatan Hukum Progresif, Jakarta: Sinar Grafika, 2020.

Marzuki, Peter Mahmud, Penelitian Hukum, Jakarta: Kencana Prenada Media Group, Surabaya, 2013.

NN, Laporan Hasil Penyelarasan Naskah Akademik Rancangan Undang-Undang tentang Perampasan Aset Tindak Pidana", Jakarta: Badan Pembinaan Hukum Nasional Kementerian Hukum dan Hak Asasi Manusia Republik Indonesia, 2015. Ramelan, Laporan Akhir Naskah Akademik Rancangan Undang-Undang tentang Perampasan Aset Tindak Pidana, Jakarta: Pusat Perencanaan Pembangunan Hukum Nasional Badan Pembinaan Hukum Nasional Kementerian Hukum dan Hak Asasi Manusia RI, 2012.

Santosa, Bima Priya, dkk., Lembaga Pengelola Aset Tindak Pidana, Jakarta: Paramadina Public Policy Institute, 2010.

Simandjuntak, Nikolas, Acara Pidana Indonesia Dalam Sirkus Hukum, Jakarta: Ghalia Indonesia, 2009. 
Sudirman, Antonius, Hati Nurani dan Putusannya Suatu Pendekatan dari Perspektif Ilmu Hukum Perilaku (Behavior Jurusprudence) Kasus Hakim Bismar Siregar, Bandung: Citra Aditya Bakti, 2007.

Witanto, Darmoko Yuti dan Arya Putra Negara, Diskresi Hakim: Sebuah Instrumen Menegakkan Keadilan Substantif dalam Perkara-Perkara Pidana, Bandung: Alfabeta, 2013

\section{Jurnal dan Makalah}

Mars, Yusuf, Herman, Handrawan, “Analisis Hukum Pembuktian Terhadap Putusan Bebas dalam Kasus Tindak Pidana Narkotika (Studi Putusan Pengadilan Negeri Kendari Nomor: 405/Pid.Sus/2016/PN. Kdi," Halu Oleo Legal Research, Volume 1, Issue 2, August 2019.

Siswahyudi, Arto, Sabrina Hidayat, Oheo K.Haris, "Kebijakan Hukum Pidana dalam Pemidanaan Tindak Pidana Illegal Logging", Halu Oleo Legal Research, Volume 2, Issue 3, Desember 2020. 